\title{
Ensuring the Sustainable Development of an Industrial Enterprise on the Principle of Compliance-Safety
}

\author{
PETRO PERERVA*1, TETIANA KOBIELIEVA ${ }^{2}$, VOLODYMYR KUCHINSKYI ${ }^{3}$, SERGII GARMASH ${ }^{4}$, \\ TARAS DANKO 5 \\ 1,2,3 Department of Management of Innovative Entrepreneurship and International Economic Relations, \\ NATIONAL TECHNICAL UNIVERSITY “KHARKIV POLYTECHNIC INSTITUTE”, UKRAINE. \\ E-mail: pgpererva@gmail.com \\ "Department of Foreign Languages, NATIONAL TECHNICAL UNIVERSITY "KHARKIV POLYTECHNIC INSTITUTE", \\ UKRAIINE. \\ ${ }^{5}$ Department of Finance and International Business, NATIONAL TECHNICAL UNIVERSITY "KHARKIV \\ POLYTECHNIC INSTITUTE", UKRAINE.
}

\begin{abstract}
This article examines and explains the necessity and importance of studying the conceptual provisions of sustainable development of enterprises and organizations in the real sector of the economy, taking into account the current environmental, economic, social situation. Also, the work is developing scientific and theoretical provisions on increasing the level of safety of industrial enterprises. Special attention is paid to studying the theoretical and methodological foundations of the concept of "compliance-safety" and the development of methodological foundations of its potential use in the current conditions of the Ukrainian economy to increase the level of sustainable development of enterprises in the real sector of the economy.

After analyzing the current state, methodological and practical recommendations, which are associated with potential changes in the number of compliance-safety violations in the domestic economy, were formed. In this regard, the scientific community was invited to expand the terminology base by introducing the terms "compliance safety", which should be formulated based on the current understanding of the term "compliance", as well as close to the concept of "economic security" and "sustainable development". This approach makes it possible to significantly impact the sustainability of the development of industrial enterprises and the economy of the state as a whole. Thanks to this definition, it is possible to consider the dynamics of the compliance safety indicator in determining the sustainable development of an enterprise and determine the size and importance of the impact of micro and macro factors on safety. In this work, special theoretical and methodological provisions and methodological recommendations were developed for assessing the value of a comprehensive compliance safety indicator. The authors' proposals were tested at many machine-building enterprises of the North-Eastern industrial region of Ukraine.
\end{abstract}

Keywords: Compliance-Safety, Industrial Enterprise, Sustainable Development

JEL Classification: L 


\section{Introduction.}

In modern conditions and processes of economic growth and globalization of national economies, the fastest possible transition of business entities to sustainable development is becoming more and more relevant. It should be understood that all industrial enterprises are the first links in the economic process. It is they who determine the efficiency of the economy and the entire state as a whole.

In Ukraine, given the complicated foreign policy and economic situation, one cannot but think and care about one's future. Thus, creating a strategy for sustainable economic development for promising periods is becoming more and more relevant. The experience of achieving indicators of sustainable economic growth in current geopolitical and economic conditions is a clear understanding of the essence of the process, all the consequences and potential crisis manifestations. It is essential to single out positive and negative factors that will contribute to the development or deceleration of the state's economy as a whole [1, 2]. In this regard, the importance and relevance of determining and justifying the directions, conditions, and factors for achieving sustainable development of the national economy and its capabilities to meet the current needs of the state increases significantly. First of all, it is necessary to consider the principles and features of the work of the real sector of the economy and fully use the production capacities of industrial enterprises and ensure the necessary scientific and technical level of their products.

\section{Analysis of literature data and problem statement.}

Researchers consider the current concept of sustainable development in an overwhelming number of cases through the prism of a triune approach, which implies the inclusion of three components in the definition of sustainable development: economic, social and environmental indicators [2, p. 96]. It will make it possible to reproduce the available results of such studies. The main prerequisites for the emergence of such a concept were the results of the "Club of Rome" work, the creators of which drew attention to a certain dependence of the development of three essential factors: environmental, economic and social [3; 4]. In 1983, at the initiative of the UN, the International Commission on Environment and Development (ICED) was created, headed by the Prime Minister of Norway G.H. Brundtland. The first report was presented in April 1987 at the 42nd session of the UN General Assembly, when representatives of the commission spoke about the plans for the long-term development of humankind, which was called "Our Common Future." This report was the first to formulate the concept of "sustainable development", which is most widely disseminated in various legal sources and scientific literature. One of those who became the founder of the development of this term is Professor of Economics Edward Barbier, who in his work in 1987 formulated the idea that the task of protecting the natural environment and achieving high rates of socio-economic development are not only not contradictory, but, on the contrary, mutually amplifying [5].

At the same time, the American economist, who was also a supporter of the triune approach, J. Sachs, in his own work "Age of Sustainable Development", defined the concept of sustainable development as "socially inclusive and environmentally sustainable economic growth" (Fig. 1). At the same time, he emphasized that the growth of the world's leading economies did not meet the criteria for sustainable development without crises [6]. Moreover, J. Sachs singled out the fourth obligatory element - the managerial one, with the help of which he pointed out that to ensure the qualitative characteristics of political institutions and the decisions made by the authorities, the adoption of high-quality government decisions is required. In his opinion, they can be of decisive importance in implementing some of the goals and objectives of long-term development stated in the new version of the UN agenda [6].

It should be noted that a significant area remained outside the field of researchers, which was associated with the development of security policy, which is a prerequisite for ensuring sustainable development. It also enabled the world's economies to combat negative factors such as corruption, 
fraud, money laundering, terrorist financing, and violation of laws and regulations. It should be noted that such problems are also inherent in the Ukrainian economy; thus, a crucial task is their detailed study and research to obtain ways to minimize or eliminate them.

Many authors [1-14] contain studies of the factors and conditions for achieving stable development of industrial enterprises using three leading indicators: economic, environmental and social. At the same time, most of the research on the formation and practical implementation of the concept of sustainable development relies on these components. O. Latisheva [2], Yu. Kharazishvili [8] adheres to a similar point of view. In their opinion, the economic, social and environmental components are more consistent with the principles of sustainable development of the state and its subjects.

The point of view of $O$. Novikova et al. [1] is somewhat different, which proposes to leave only the ecological component of sustainable development, since, in her opinion, it is it that demonstrates the most significant connection with sustainable development and economic and social factors do not exert such an influence.

It should be understood here that the specifics of state, regional, economic, social and industrial policies in legislation, concepts and strategies are determined by the needs and mechanisms of Ukraine's transition to sustainable development $[1,12]$. At the same time, researchers also pay their attention to the great importance and necessity of ensuring a security component concerning the overall development of the country, emphasizing that it is the uncertainty of the principles and ideas of Ukrainian legislation that is the greatest threat to the national security of Ukraine $[1, p .10]$. When considering the problem of sustainable development through the prism of the use and development of comprehensive resources, reserves and capabilities of nature, a system is created to formalize the systemic features of the country's sustainable development. Similar studies have been demonstrated in the scientific works of L. Melnik [7], O. Bezprozvannykh [9]. In their works, these researchers do not single out any components of sustainable development, considering the resource approach as basic in solving problems and tasks of sustainable development. The primary attention in these works is paid to the prerogative of national development, which does not pay due attention to an industrial enterprise's place, role, and tasks.

However, in our opinion, the full implementation of the concept of sustainable development is inextricably linked with its appropriate provision at all levels of government (national, regional, sectoral, enterprise). Effective development can be achieved only through the successful operation of the primary link of the economic system. This industrial enterprise plays a crucial role in the development and functioning of modern society. The critical part of the enterprise is in the center of scientific researches of N. Tkachova [10;11] and O. Gutsan [12], who indicate that the basic provisions of the concept of sustainable development can be implemented at the level of an individual industrial enterprise.

The formation of basic provisions and components of sustainable development is impossible without a theoretical justification of this term. Here, too, researchers do not have a single approach. According to some economists $[1 ; 2 ; 11]$, sustainable development is usually understood as the ability to resist negative influences, mainly natural forces, the ability to prevent or mitigate declines in production. Sustainable production can only be recognized as one that meets a specific set of specific needs at minimal cost and in the shortest possible time, based on available resources and real opportunities for efficient use [13]. According to other scientists, sustainable development involves the transition from the current use of resources to the economy of their systemic reproduction $[3 ; 6 ; 10]$. The core of sustainable development is the subsystem of reproduction of quality resources, the main among which is human potential. From the general point of view, sustainable development should be understood as the development that considers the balance of interests of present and future generations $[14 ; 15]$. Thus, the basis for forming the concept of sustainable development should be the idea of dynamically balanced interaction of economic, social and environmental spheres of social development. 
The study of the available scientific literature [1-22] allowed among the problems that hinder the processes of sustainable development of the Ukrainian economy from singling out the issues of the state in ensuring its economic security, which reduces the role of the state, insufficient effectiveness of existing tools and levers to stimulate environmentally friendly energy-saving technologies, lack of complexity in solving problems of rationalization of nature management and nature protection. All this necessitates fundamental research into the nature of economic relations in terms of real achievement of the conceptual provisions of sustainable development of the economy and its real sector.

\section{The purpose and objectives of the study.}

The article aims to further develop the conceptual provisions of sustainable development of the national economy and its real sector by taking into account the security component. Achieving this goal provides a real opportunity to determine the direction of sustainable development of industrial enterprises by ensuring their economic security in the current period from the future standpoint.

The following tasks are set to achieve this aim:

- to develop theoretical and methodological principles of ensuring the economic security of the enterprise, taking into account the possibility of significant reduction (complete elimination) of cases of various types of compliance crimes;

- to develop a mechanism for the formation of compliance security in the system of sustainable development of industrial enterprises

- developed theoretical and methodological provisions and guidelines for assessing the value of a comprehensive indicator of compliance safety at many machine-building enterprises of the NorthEastern industrial region of Ukraine.

\section{Materials and research methods to ensure sustainable development of industrial enterprises based on compliance-safety.}

The theoretical-methodological and methodical basis of the research is formed by analyzing leading scientists on sustainable development and safety. The information base of such studies made it possible to identify omissions related to the fragmentary approaches to determining the level of economic security of industrial enterprises and its impact on the level of sustainable development of the enterprise. Researchers ignored the existing compliance violations, which are extremely characteristic of industrial enterprises and organizations' current production and commercial activities (total non-compliance with existing legislation, corruption, fraud, raiding, money laundering, violations of corporate ethics, etc.).

To achieve the goal of research and to solve the tasks in the article used general and special methods: an abstract-logical and comparative analysis - in the study of the nature and role of sustainable development in the activities of industrial enterprises; grouping and systematization - in determining the main types of compliance crimes, typical of machine-building production; systemstructural method, methods of induction, deduction and logical generalizations - in the development of the mechanism of compliance safety in the system of sustainable development of industrial enterprises; tabular method - to visualize the results of assessing the state of compliance security in Ukraine as a whole and enterprises of the real sector of the economy; method of expert assessment to develop a scale of differentiation of economic and compliance-safety of the enterprise.

\section{The results of the study.}

Based on the purpose and objectives of the article, we propose to consider the conceptual scheme of the components of sustainable development in an expanded form, including the security direction (Fig. 1). 
Figure 1. Components of sustainable development of an industrial enterprise

\section{Sustainable development of an industrial enterprise}

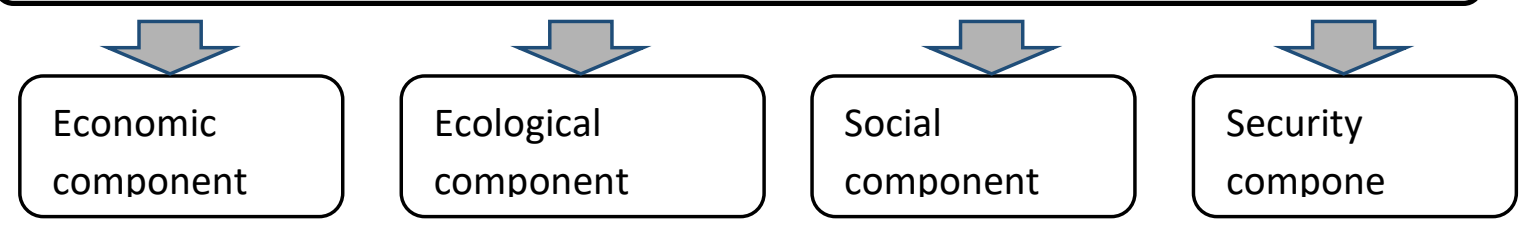

Source: author's development

In the mechanism of ensuring the national security of any country, the necessary level of its economic security ensures sustainable, crisis-free socio-economic development of the entire economy. Defining the essence of the term "economic security" can be based on the two most common points of view. The first of them [16; 17] defines this term as the ability of the national economy to ensure economic security and protection of commercial and industrial interests of each business entity (enterprise, region, industry and country as a whole) and, accordingly, their sustainable development. The second point of view [18; 19] defines economic security as protecting each of the country's most critical areas and industries from possible compliance-safety threats, which we demonstrated in Fig. 2.

Ukrainian legislation proposes to use many legislative acts in the field of corruption $[12 ; 18 ; 20]$, but on their basis, it is necessary to develop specific scientific and methodological proposals and guidelines for the actual implementation of these laws in the industrial enterprises of our country. One of such essential directions, in our opinion, is the use of the concept of compliance for the needs of increasing economic security and the level of sustainable development.

Figure 2. The most important indicators (factors, components) of economic security of the country

Achieving stable development of the whole country (main macroeconomic indicator)

Macroeconomic
protection
(external
threats)

Economic independence (enterprises, industries, regions and the country as a whole)
Achieving stable development of each business entity (region, industry, enterprise)

\section{Source: authors' development}

The concept of "compliance-safety" is to some extent an original, underused term in the Ukrainian scientific worldview; it was borrowed from the US Law "On Corruption Abroad" and similar laws of other countries [16, p. 23]. The term "compliance" in these documents is presented as the appropriate actions that businesses (legal entities) must take following the requirements of these laws as a whole. To the greatest extent, this refers to the most dangerous types of compliance violations (corruption, fraud, money laundering and terrorist financing (VG / FT), violations of the rules and regulations of corporate ethics, etc.). In our country, the definition of the term "compliance-safety" is enshrined in resolving the Board of the National Bank [19]. According to this regulation, compliance means the subject's compliance with applicable laws, market standards, 
internal regulations and business or organization regulations. In our opinion, these tasks, which reproduce the economic essence of compliance, are crucial for the Ukrainian economy.

We propose to introduce into scientific terminology the definition of "compliance-safety of the enterprise" to take into account the real state of the enterprise in the field of compliance with applicable laws, regulations, instructions, regulations and rules of corporate ethics. This term characterizes the degree of protection of the most important results of work and interests of the enterprise from various compliance violations and the achievement of sustainable development of organizations, institutions, industrial enterprises and the Ukrainian economy as a whole. The proposed definition allows the dynamism of the compliance safety indicator while ensuring the sustainable development of the industrial enterprise and determining the importance of both microand macro-factors influencing the compliance safety indicator; to offer as an essential indicator the level of sustainable development of the industrial enterprise.

The Professional Association of Certified Anti-Corruption and Fraud Experts Association (ACFE) conducts an annual global survey of industrial enterprises in various countries, including Ukraine [20]. According to this study, the vast majority of industrial enterprises agree with the study results, which notes that corruption is widespread in Ukraine. Over the past five years, statistical studies show that statement was supported by $95 . . .98 \%$ of respondents, evidenced by the data in Table 1 .

Table 1. Share of Ukrainian enterprises and organizations that answered the question positively

\begin{tabular}{|l|c|c|c|c|c|}
\hline \multicolumn{2}{|c|}{ Contents of the question } & \multicolumn{5}{|c|}{ Year of the survey } \\
\cline { 2 - 6 } & $\mathbf{2 0 1 4}$ & $\mathbf{2 0 1 5}$ & $\mathbf{2 0 1 6}$ & $\mathbf{2 0 1 7}$ & $\mathbf{2 0 1 8}$ \\
\hline $\begin{array}{l}\text { Do you confirm the statement that corruption is } \\
\text { quite widespread in Ukraine }\end{array}$ & $97 \%$ & $96 \%$ & $95 \%$ & $95 \%$ & $95 \%$ \\
\hline $\begin{array}{l}\text { Has your company encountered corruption in its } \\
\text { business activity }\end{array}$ & $91 \%$ & $88 \%$ & $81 \%$ & $91 \%$ & $92 \%$ \\
\hline $\begin{array}{l}\text { In your opinion, has the level of corruption in } \\
\text { Ukraine decreased over the last year? }\end{array}$ & $28 \%$ & $28 \%$ & $46 \%$ & $35 \%$ & $32 \%$ \\
\hline
\end{tabular}

Source: based on ACEF data [21]

But, in our opinion, it is challenging to draw unambiguous conclusions on the growth of economic crime in this country. The data of research obtained as a result of the survey can be explained, in particular, by the increase in the indicators of detected compliance crimes at industrial enterprises. Available statistics confirm this statement. Today's percentage of ukrainian enterprises that most suffer from manifestation of compliance violations is 31... 51\% [22]. In reality, the share of enterprises and organizations with corruption is significantly more extensive; it is actually in the range of $81 . .91 \%$ [22]. This discrepancy in the statistics is explained, in our opinion, by the fact that a significant part (about half) of the actual compliance crimes remain out of the attention of both enterprises and law enforcement agencies, these violations are not recorded, economic losses from their presence are not calculated.

Today in Ukraine, such compliance crimes as fictitious charitable assistance, raiding, misappropriation of someone else's property, acquisition of non-existent types of goods and services, various illegal payments to formally unrelated companies, corruption interaction with law enforcement agencies are becoming more and more popular as institutions through multiple intermediaries, the non-transparent structure of marketing costs, implementation of fictitious investment projects, cybercrime, fraud in procurement and management of production staff. Cybercrime usually includes unauthorized tracking and control (monitoring) of databases and transactions conducted by enterprises and hacking of personal e-mail accounts of financial subscribers. Based on such opportunities for compliance violations, various divisions of industrial enterprises (marketing and procurement services, departments for sales, investment activities, etc.) often tend to obtain significant compliance risks to become a source of economic crimes (compliance violations) in this area. Statistics on the most influential and essential types of compliance crimes in various sectors of the domestic economy are given in Table 2. 
Table 2. The most important types of compliance crimes in the domestic and world economy (the share of

\begin{tabular}{|c|c|c|c|c|c|c|c|}
\hline \multirow{2}{*}{$\begin{array}{c}\text { Types of compliance } \\
\text { crimes }\end{array}$} & World & Poland & $\begin{array}{c}\text { Czech } \\
\text { Renublic }\end{array}$ & Russia & Hungary & \multicolumn{2}{|c|}{ Ukraine } \\
\hline & \multicolumn{5}{|c|}{2018} & 2016 & 2018 \\
\hline $\begin{array}{l}\text { Appearances of bribery and } \\
\text { corruption }\end{array}$ & 24 & 18 & 13 & 40 & 15 & 57 & 72 \\
\hline Consumer fraud & 28 & 22 & 18 & 30 & 24 & 22 & 18 \\
\hline $\begin{array}{l}\text { Misappropriation of } \\
\text { property illegally }\end{array}$ & 44 & 36 & 28 & 52 & 38 & 61 & 47 \\
\hline $\begin{array}{l}\text { Compliance violations in } \\
\text { the field of taxes }\end{array}$ & 5 & 4 & 3 & 5 & 3 & 25 & 24 \\
\hline $\begin{array}{l}\text { Infringement of intellectual } \\
\text { property rights }\end{array}$ & 8 & 4 & 3 & н/д & 5 & 28 & 26 \\
\hline $\begin{array}{l}\text { Fraud in enterprises during } \\
\text { procurement }\end{array}$ & 22 & 17 & 16 & 35 & 13 & 25 & 33 \\
\hline $\begin{array}{l}\text { Manifestations of unfair } \\
\text { competition }\end{array}$ & 7 & 5 & 3 & н/д & 4 & 21 & 19 \\
\hline Management fraud & 11 & 8 & 6 & 18 & 7 & 29 & 34 \\
\hline Cybercrime & 30 & 23 & 18 & 25 & 15 & 26 & 32 \\
\hline $\begin{array}{l}\text { In the field of business } \\
\text { conduct }\end{array}$ & 27 & 23 & 19 & 22 & 17 & 18 & 17 \\
\hline Money laundering & 10 & 6 & 5 & 14 & 7 & 22 & 21 \\
\hline $\begin{array}{l}\text { Violation of financial } \\
\text { statements }\end{array}$ & 20 & 12 & 15 & 19 & 14 & 14 & 13 \\
\hline Insider trading & 7 & 4 & 4 & 10 & 8 & 8 & 9 \\
\hline Other & 6 & 9 & 6 & 7 & 8 & 7 & 3 \\
\hline
\end{tabular}

Source: based on ACEF data [21]

The data presented in Table 2 allow us to conclude that bribery and corruption remain the most common types of economic crimes, which negatively impact the results of production and commercial activities of Ukrainian enterprises and organizations (Table 2). It is enough to pay attention to the fact that only in 2016-2018, about half of the surveyed enterprises (48\%) suffered from these compliance crimes, and every third Ukrainian enterprise $(33 \%)$ mentioned that its top management received offers to give or take a bribe. According to the study results, the most common types of compliance crimes, which are most often dealt with by Ukrainian companies and organizations, are misappropriation of someone else's property (46\%), fraud in procurement enterprises (33\%) and compliance crimes in personnel management. (34\%), the presence of cybercrime (32\%). For the next few years, the forecast of Ukrainian respondents is negative: representatives of domestic enterprises believe that bribery and corruption will remain the most serious economic crimes for their companies. In other countries close to Ukraine (Czech Republic, Hungary, Poland, Russia) and around the world, the most common type of economic compliance crime is the misappropriation of tangible assets. In second place are manifestations of bribery and corruption. The third most common type of compliance crime is the manifestation of fraud in various types of goods and services. Worldwide, misappropriation of assets also retains a leading position, followed by customer fraud and cybercrime.

For each of the types of compliance crimes, there are certain forms of their actual implementation, the use of which in practice and these illegal actions are carried out (Table 3 ). 
Table 3. The most common forms of compliance crimes at enterprises in Ukraine (as a percentage)

\begin{tabular}{|c|c|c|c|c|c|c|c|}
\hline \multirow{2}{*}{$\begin{array}{c}\text { Form of compliance } \\
\text { crime }\end{array}$} & \multicolumn{3}{|c|}{ Year of observation } & \multirow{2}{*}{$\begin{array}{c}\text { Form of compliance } \\
\text { crime }\end{array}$} & \multicolumn{3}{|c|}{ Year of observation } \\
\hline & 2017 & 2018 & 2019 & & 2017 & 2018 & 2019 \\
\hline Requirement of bribe & 68 & 70 & 69 & $\begin{array}{l}\text { Claiming sponsorship } \\
\text { funds }\end{array}$ & 7 & 6 & 5 \\
\hline $\begin{array}{l}\text { Abuse of official } \\
\text { position }\end{array}$ & 69 & 64 & 65 & $\begin{array}{l}\text { Claiming funds to win } \\
\text { the tender }\end{array}$ & 27 & 32 & 34 \\
\hline $\begin{array}{l}\text { Seeking a partnership } \\
\text { with a branch of the } \\
\text { company }\end{array}$ & 25 & 23 & 24 & $\begin{array}{l}\text { Harassment of bribes } \\
\text { to stop illegal pressure }\end{array}$ & 45 & 46 & 44 \\
\hline Claiming donations & 18 & 19 & 19 & Other & 4 & 4 & 5 \\
\hline
\end{tabular}

The data in Table 3 show that the most common type of compliance crimes is abuse of office (65... $68 \%$ ) or demand (giving) a bribe (68... 70\%). In this regard, we note that the change in the factor "demand (giving) a bribe" has not been observed recently; there are no noticeable trends in its transformation. To some extent, the number of "abuse of office" cases has decreased somewhat (from 69\% in 2017 to 65\% in 2019), which, in our opinion, can be explained by the creation in recent years and active work in Ukraine of anti-corruption law enforcement agencies.

Their compliance security program should prevent the actual manifestations of compliance crimes in organizations and enterprises. The mechanism of formation, compliance and safety of an industrial enterprise as a category of economy, determining its place in the system of sustainable development and organizational and economic principles of practical use are presented in Fig. 3.

\section{Conclusions.}

In the conducted research based on the detailed analysis and generalization of theoretical and methodical approaches, modern conceptual provisions of sustainable development of the industrial enterprise from positions of a safety component are developed, practical approbation of the offered practices at the level of the industrial enterprise is carried out. Achieving sustainable, effective development of an industrial enterprise is reflected in achieving a system of goals (social, economic, environmental). In this case, profit is no longer the ultimate goal, which focuses on the top management of the industrial enterprise. It is one of the economic goals and performs a critical task to achieve the entire system of goals of the enterprise. It is proposed to consider a criterion for assessing the sustainable, effective development of the enterprise, not only the standard components (economic, social, environmental) but also indicators of economic security. Within the security component, the most important, according to the authors, is to take into account a significant factor - compliance security. The concept of "compliance-security" is recommended to be defined based on the content of both the term "compliance" and the definitions of "economic security" and "sustainable development", as a measure of protection of the most important results and interests of the company from various compliance violations and achieving sustainable both industrial enterprises and the entire economy of our country.

The introduction of this concept into scientific circulation allows industrial enterprises to concentrate as much as possible on overcoming such negative phenomena inherent in the Ukrainian economy as corruption, fraud, money laundering and terrorist financing, violation of laws and regulations, corporate ethics.

The solution of significant problems in the security direction of sustainable development is impossible without coordination of actions and strategies at all levels - from the national economy as a whole to the level of industry and individual enterprises. The result of the systematic solution of economic, environmental, social and security problems at all levels will be the achievement of sustainable development at each of them. 
Figure 3. The mechanism of compliance security in the system of sustainable development of industrial

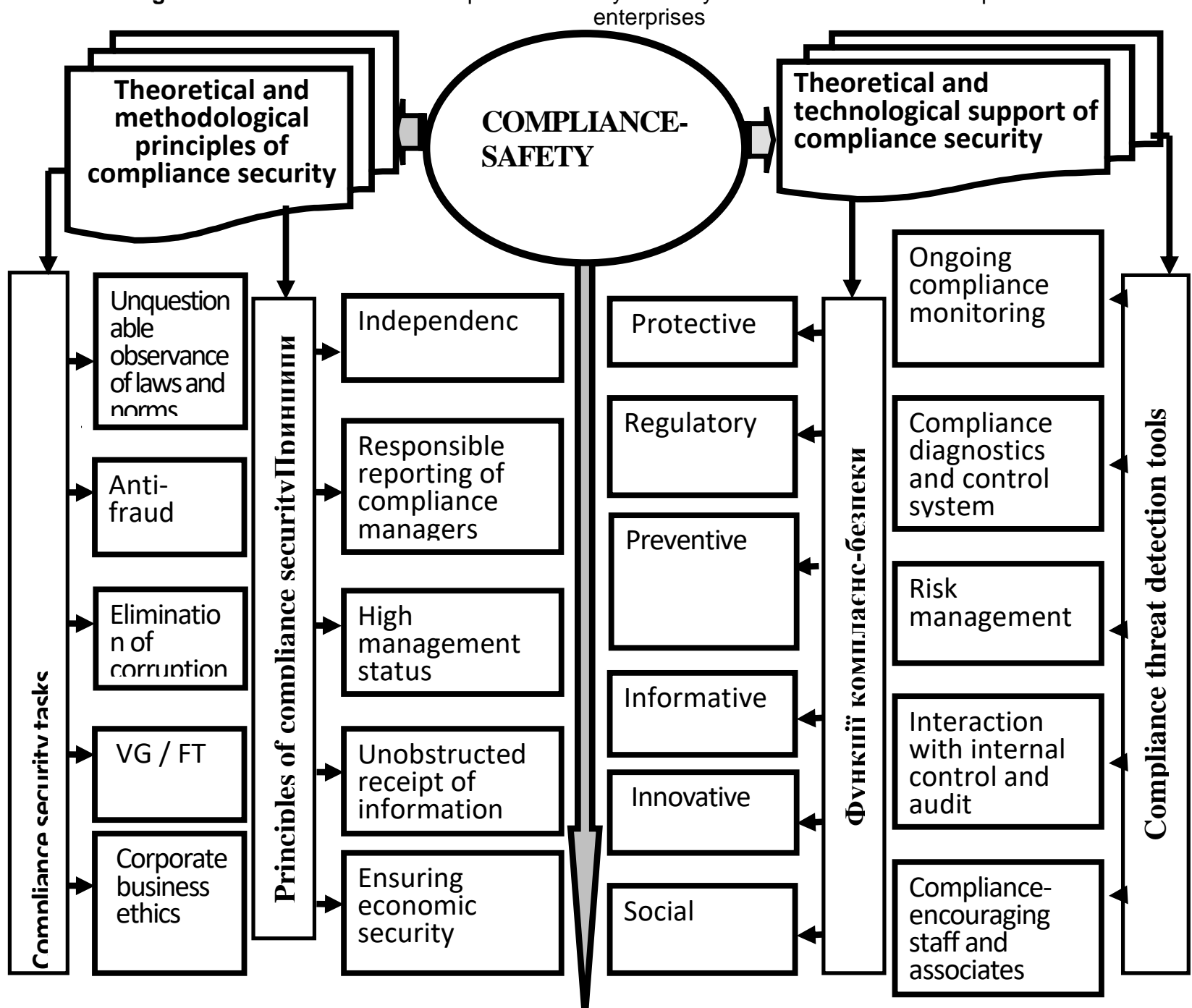

Organizational and economic component of the formation of the compliance system
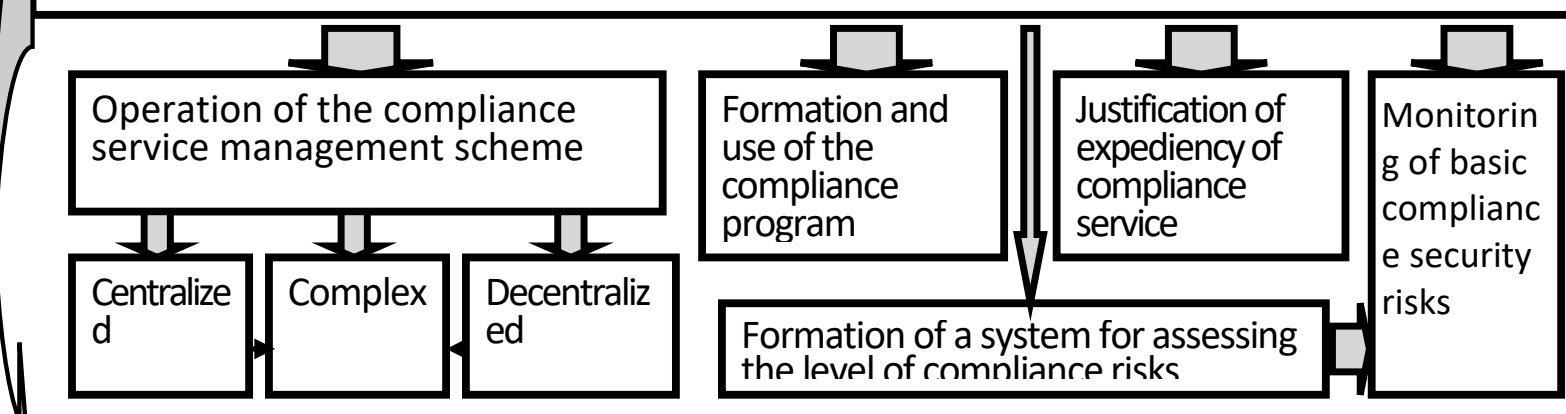

Calculation of the value of a complex (integrated) indicator of compliance safety of the enterprise

Estimation of economic efficiency of activity of the enterprise on maintenance of the compliance safety 
The set of obtained methodological, theoretical and methodological and scientific and practical results is based on the study of the essence and content of the concept of compliance, scientific and methodological adaptation to the practice of industrial and commercial activities of industrial enterprises, as well as improving the organizational and economic mechanism for compliance. It grounds to assert the implementation during the study of an important scientific and practical task to enhance the sustainable development of industrial enterprises and the entire economy of our country.

\section{References}

1. Novikova, O.F., Amosha, O.I., Antonyuk V.P. et al. (2012). Sustainable development of the industrial region: social aspects. NAS of Ukraine, Institute of Economics and Industry, Donetsk, $534 \mathrm{p}$.

2. Latisheva, O.V. (2016). Analysis of the state of the economic component of sustainable development of industrial enterprises of Ukraine. Theoretical and practical aspects of economics and intellectual property, 14, pp. 95-103.

3. Mesarovic, M., Pestel, E. (1974). Mankind at the Turning Point: The Second Report to the Club of Rome. New-York: E. P. Dutton and Co. Inc. 145 p.

4. Kharazishvili, Y., Kwilinski, A., Grishnova, O., Dzwigol, H. (2020). Social Safety of Society for Developing Countries to Meet Sustainable Development Standards: Indicators, Level, Strategic Benchmarks (with Calculations Based on the Case Study of Ukraine). Sustainability, 12(21), 8953. https://doi.org/10.3390/su12218953

5. Barbier, E. (1987). The Concept of Sustainable Economic Development. Environmental Conservation, 14(2).

6. Sachs, J. (2015). The Age of Sustainable Development. Columbia University Press, 544 p.

7. Melnik, L.M. (2018). Ensuring sustainable development of industrial enterprises through business process management: theory, methodology, practice. Ternopil, FOP Palyanytsya V.A., 367 p.

8. Kharazishvili, Yu.M., Lyashenko, V.I. (2017). Problems of assessment and integrated indices of sustainable development of Ukrainian industry from the standpoint of economic security. The economy of Ukraine, 2, pp. 3-23.

9. Pererva, P., Besprozvannykh, O., Tiutlikova, V., Kovalova, V., Kudina, O., Dorokhov, O. (2019). Improvement of the Method for Selecting Innovation Projects on the Platform of Innovative Supermarket. TEM Journal, 8(2), pp. 454-461. URL: DOI: 10.18421/TEM82-19

10.Perereva, P., Kobielieva, T., Tkachova, N., Tkachov, M., Diachenko, T. (2021) Management of relations with enterprise stakeholders on the basis of value approach. Problems and Perspectives in Management, 19(1), pp. 24-38. URL: http://dx.doi.org/10.21511/ppm.19(1).2021.03

11.Kosenko, O., Cherepanova, V., Dolyna, I., Matrosova, V., Kolotiuk, O. (2019). Evaluation of innovative technology market potential on the basis of technology audit. Innovative Marketing, 15(2), pp. 30-41. doi:10.21511/im.15(2).2019.03

12.Pererva, P., Hutsan, O., Kobieliev, V., Kosenko, A., Kuchynskyi, V. (2018). Evaluating elasticity of costs for employee motivation at the industrial enterprises. Problems and Perspectives in Management, 16(1), pp. 124-132. URL: DOI: http://dx.doi.org/10.21511/ppm.16(1).2018.12

13.Miśkiewicz, R, Wolniak, R. (2020). Practical Application of the Industry 4.0 Concept in a Steel Company. Sustainability, 12(14), 5776. URL: https://doi.org/10.3390/su12145776

14.Dzwigol, H., Dzwigol-Barosz, M. (2020). Sustainable Development of the Company on the Basis of Expert Assessment of the Investment Strategy. Academy of Strategic Management Journal, 19(5), pp. 1-7. 
15.Kwilinski, A., Ruzhytskyi, I., Patlachuk, V., Patlachuk, O., Kaminska, B. (2019). Environmental Taxes as a Condition of Business Responsibility in the Conditions of Sustainable Development. Journal of Legal, Ethical and Regulatory Issues, 22(SI2) 1544-0044-22-SI-2-354: 1-6. Retrieved from https://www.abacademies.org/articles/Environmental-taxes-as-a-condition-of-businessresponsibility-in-the-conditions-of-sustainable-development-1544-0044-22-SI-2-354.pdf

16.The Foreign Corrupt Practices Act of 1977 (FCPA). URL: https://en.wikipedia.org/wiki/Foreign_Corrupt_Practices_Act

17.On prevention of corruption: Law of Ukraine of 14.10.2014 №1700-18. URL: zakon.rada.gov.ua.

18.On prevention and counteraction to legalization (laundering) of proceeds from crime, terrorist financing, and the proliferation of weapons of mass destruction: Law of Ukraine of October 14, 2014, № 1702-VII; update date: November 24 2018. URL:

http://zakon3.rada.gov.ua/laws/show/1702-18

19.Report to the Nation 2018. Global Study on Occupational Fraud and Abuse / Association of Certified Fraud Examiners. URL: https://www.acfe.com/report-to-the-nations/2018.

20.On approval of the Regulation on the organization of internal control in banks of Ukraine: Resolution of the Board of the National Bank of Ukraine № 867 of December 29, 2014: URL: http://zakon2.rada.gov.ua/laws/show/ v0867500-14/page?text

21.Transparency International EU: official site. URL: http://transparency.eu

22. On registered criminal offenses and the results of their pre-trial investigation (statistical information for 2013-2018). Prosecutor General's Office of Ukraine: official website. URL: http://www.gp.gov.ua 